\title{
REDUKSI NILAI MORAL, BUDAYA, DAN AGAMA TERHADAP IMPLEMENTASI PENDIDIKAN KARAKTER DI SEKOLAH
}

\author{
Idris HM Noor \\ e-mail: idrishmnoor@yahoo.com \\ Pusat Penelitian Kebijakan Balitbang Kemdibud
}

\begin{abstract}
Abstrak: Pendidikan karakter tidak terlepas dari nilai moral, budaya bangsa, dan agama. Bangsa yang menjunjung tinggi aturan agama dan prinsip-prinsip budaya bangsanya akan selalu teguh mempertahankan karakter bangsanya. Bangsa yang besar diukur dari ketahanan moral dan keteguhan melaksanakan karakter bangsanya. Pendidikan karakter tidak tercipta dengan sendirinya tapi dibina dan dipupuk sejak anak dalam keluarga. Keluarga merupakan benteng pertama dan utama dalam mendidik anak menjadi orang dewasa dan warga negara yang bertanggung jawab. Salah satu komponen yang sangat berpengaruh terhadap menurunnya nila karakter bangsa adalah melemahnya implementasi nilai-nilai agama, moral, dan budaya bangsa. Pendidikan merupakan salah satu benteng ketahanan nilai-nilai karakter bangsa. Oleh karena itu, pendidikan karakter di sekolah perlu terus dilaksanakan secara terpadu dalam pembelajaran dan diatur dalam kurikulum. Kajian ini menggunakan metode analisis dokumen. Hasil kajian menyimpulkan beberapa faktor yang mempengaruhi melemahnya pendidikan karakter di kalangan pendidikan antara lain melemahnya nilai moral, agama, dan budaya. Beberapa tindakan yang perlu dilakukan oleh kementerian pendidikan dalam mengatasi melemahnya nilai moral bangsa di lingkungan pendidikan sekolah adalah bekerjasama dengan media seperti televisi(TV) untuk meggiatkan kembali tampilan budaya-budaya asli Indonesia yang dulu sering ditampilkan di TV seperti: acara wayang, kesenian daerah, kerajinan khas daerah, budaya khas gotong royong. Beberpa cara praktis dalam mengimplementasikan nilai karakter bangsa di sekolah yaitu dengan melaksanakan pembelajaran karakter bangsa terintegrasi dalam semua bidang studi.
\end{abstract}

Kata kunci: moral, budaya, agama, bangsa, karakter, sekolah

\section{REDUCTION OF MORAL VALUES, CULTURE, AND RELIGION TOWARDS THE IMPLEMENTATION OF EDUCATION CHARACTER AT SCHOOL}

\begin{abstract}
Educational character cannot be separated from the values of moral, nation culture, and religion. The nation that keeps tightly on the rule of religion and the principle of its culture will always be conducting its culture. The strongest nation is characterized by the implementation of its characters. The education character cannot be formed spontaneously but it is developed since the children be at home. The family is the first and main defends in educating children for an adult people and for a responsible citizenship. One of the components which influences the reducation of nation character is that the lack of implementation of moral values, religion, and nation culture. Education is one of defends of nation character values. Therefore, education character at school should continuously be implemented integratively in instructional process and it should be put in the curriculum. This analysis uses document study method. The result of analyisis concludes some factors which affect the lack of education character in education i.e: the reduction of the moral values, religion, and culture. Some actions that the Ministry of Education and Culture should do in overcoming the lack of nation moral values in education sector such as at school is that to work collaboratively with media such as television to forcast Indonesian culture as it was done before on television such as: wayang, local dance or song, specific local industry, and community self help. Some simple strategies in implementing character values at school is that by implementing instruction of nation character integratively with all subjects.
\end{abstract}

Keywords: moral, culture, religion, character, school

\section{PENDAHULUAN}

Melemahnya budaya dan karakter bangsa di kalangan siswa adalah salah satu isu yang menarik 
perhatian masyarakat terutama di kalangan ahli pendidikan, pengamat pendidikan, dan pengamat sosial di berbagai media cetak, televisi, koran, majalah, internet, handphone, dan dalam berbagai seminar, baik pada tingkat lokal, nasional, maupun internasional. Persoalan yang hangat dibicarakan adalah persoalan korupsi, kekerasan, kejahatan seksual, perusakan, perkelahian massa, kehidupan ekonomi yang konsumtif, dan kehidupn politik yang tidak kondusif. Melemahnya implementasi karakter bangsa dapat dilihat pada forum resmi, misalnya; di lembaga terhormat Dewan Perwakilan Rakyat (DPR) sering kita tonton dan saksikan dalam televisi, para wakil rakyat yang dianggap terhormat menunjukkan sifat yang melanggar norma kehidupan dan karakter bangsa kita dengan memperlihatkan sifat arogansi individu dan kelompok. Hal serupa juga kita saksikan pada tanggal 20 Mei 2011 pada Kongres Persatuan Sepak Bola Seluruh Indonesia (PSSI) di Hotel Sultan Jakarta, peserta kongres saling mengeluarkan katakata kotor dan kasar. Di Jakarta, hampir setiap minggu - dengan mengatasnamakan demokrasi - terjadi demonstrasi yang juga para pemimpin demo dalam orasinya sering mengeluarkan kata-kata yang tidak pantas sebagai bangsa yang beradab dan mempunyai karakter yang harus dijunjung oleh semua masyarakat bangsa ini.

Para remaja khususnya anak didik yang menyaksikan kejadian-kejadian tersebut di atas merasa bingung dan heran, dan mereka sangat sulit untuk memahaminya karena hal tersebut berbeda dengan apa yang mereka pelajari di sekolah. Guru mengajarkan mereka melakukan sesuatu sesuai dengan norma-norma dan karakter bangsa kita dalam kehidupan sehari-hari, namun apa yang mereka lihat dalam kehidupanya di luar sekolah sangat berbeda.

Perilaku masyarakat yang banyak menyimpang dari nilai-nilai agama, moral, kebangsaan dan budaya tidak bisa dihindari oleh peserta didik yang coba-coba mengikuti perilaku tersebut. Perilaku negatif tersebut tidak menceminkan karakter bangsa dan nilai dasar yang tertuang dalam Undang-Undang Dasar 1945 yaitu nilai keagamaan dan falsafah Negara Pancasila yaitu nilai kemasyarakatan berupa nilai moral, etika, dan norma-norma yang berlaku dalam masyarakat serta nilai kenegaraan yaitu cinta terhadap tanah air dan bangsanya. Dalam Undang-Undang Republik Indonesia Nomor 20 Tahun 2003 tentang Sistem Pendidikan Nasional Pasal 3 dinyatakan bahwa "Pendidikan nasional berfungsi mengembangkan kemampuan dan membentuk watak serta peradaban bangsa yang bermartabat"
Akibat dari melemahnya nilai-nilai moral, pelaksanaan karakter bangsa Indonesia yang luhur, berdampak pada sikap negatif siswa yang terus bertambah dan sulit dihidari di hari-hari belakang ini. Hal-hal negatif yang sering dilakukan oleh remaja kita, antara lain seperti yang terungkap dalam data Badan Narkotika Nasional (BNN: 2004), lebih dari 2 juta remaja Indonesia ketagihan narkoba. Menurut komisi perlindungan anak (TVOne, 20 Maret 2012), anak-anak usia 5 tahun sudah mulai merokok, dengan peningkatan drastis, 400\%. Data dari Departemen Kesehatan Republik Indonesia (Depkes:2008) menujukkan bahwa lebih 8000 remaja terdiagnosis pengidap HIV AIDS. Kita juga melihat pergaulan bebas yang dilakukan siswa Sekolah Menengah Pertama (SMP), Sekolah Menengah Atas (SMA), dan Sekolah Menengah Kejuruan (SMK) di masyarakat, beberapa video adegan porno yang tertangkap polisi yang sempat disiarkan dalam televisi, narkoba, dan perilaku tidak jujur lainnya seperti menyontek dalam ujian, dan menyakiti teman, serta kejadian-kejadian lain yang secara terbuka dapat disaksikan oleh para remaja kita sehingga membuat kita semua, guru, dan orangtua merasa khawatir.

Namun, kita juga tidak menutup mata terhadap perbuatan dan tingkah laku positif yang ditunjukkan oleh para remaja kita, seperti: prestasi siswa kita dalam olimpiade sains tingkat dunia, kreativitas pentas seni, prestasi dalam bidang olahraga, pembuatan laptop, pembuatan kendaraan khususnya para siswa SMK, dan kreativitas positif lainnya.

Di samping dunia nyata remaja, kita juga disuguhi tontonan TV setiap hari; TV merupakan salah satu cermin budaya bangsa saat ini. Umumnya budaya yang ditampilkan terbatas pada seni suara dan seni akting, yang memang disukai pemirsa, tua muda. Acara TV umumnya mengikuti selera, bukan visi-misi yang sesuai dengan visi-misi masa depan bangsa.

Kita sekarang sudah kurang berminat lagi terhadap budaya-budaya asli Indonesia yang dulu sering ditampilkan di TV seperti: acara wayang, kesenian daerah, kerajinan khas daerah, budaya khas gotong royong Indonesia yang kesemuanya ini merupakan cermin budaya dan karakter bangsanya Indonesia. Nampaknya kita khususnya para remaja sudah mulai asing dengan budaya khas Indonesia apalagi nilai-nilai yang terkandung di dalamnya.

Untuk mengurangi tindakan-tindakan negatif yang dilakukan siswa tersebut di atas, kementerian Pendidikan Nasional menjadikan karakter bangsa sebagai sesuatu yang harus dilakasanakan di sekolahsekolah. Penempatan pendidikan karakter bangsa ini 
masih menjadi perdebatan di kalangan pemerintah, para tokoh pendidikan, pengamat pendidikan, pelaku dan pelaksana pendidikan, kepala sekolah, guru, siswa, dan perguruan tinggi terutama lembaga pendidikan dan tenaga kependidikan (LPTK) dan orangtua serta masyarakat lainnya. Dari pemikiran dan pendapat berbagai kalangan tersebut, alternatif yang banyak disarankan untuk mengatasi persoalan lemahnya budaya dan karakter bangsa ini adalah melalui pendidikan karena pendidikan dianggap sebagai salah satu alternatif yang mampu mendidik generasi muda bangsa menjadi generasi yang lebih baik. Pendidikan dianggap mampu mengembangkan kualitas generasi muda bangsa dalam berbagai aspek dan dapat memperkecil dan mengurangi penyebab lemahnya budaya dan karakter bangsa walaupun akan dapat dilihat dalam jangka waktu lama.

Berdasarkan isu-isu merosotnya nilai-nilai moral dan karakter bangsa tersebut di atas, maka masalah yang menjadi sorotan kajian ini adalah melemahnya implementasi pendidikan karakter di masyarakat yang sulit terbendung dan berpengaruh terhadap tingkah laku anomali peserta didik. Pertanyaan kajian yang sangat urgen diatasi adalah: (1) faktor apa saja mempengaruhi melemahnya pendidikan karakter di kalangan pendidikan?; (2) apa yang perlu dilakukan oleh kementerian pendidikan dalam mengatasi melemahnya nilai moral bangsa di lingkungan pendidikan sekolah; dan (3) bagaimana cara praktis dalam mengimplementasikan nilai karakter bangsa di sekolah?.

Tujuan kajian ini adalah mencari solusi alternatif yang mungkin dapat dilakukan oleh kementerian pendidikan dan jajarannya dalam mengatasi melemahnya implementasi pendidikan karakter di masyarakat yang sulit terbendung dan berpengaruh terhadap tingkah laku anomali peserta didik. Tujuan khusus kajian ini yaitu: (1) faktor yang mempengaruhi melemahnya pendidikan karakter di kalangan pendidikan; (2) tindakan yang perlu dilakukan oleh kementerian pendidikan dalam mengatasi melemahnya nilai moral bangsa di lingkungan pendidikan sekolah; dan (3) cara praktis dalam mengimplementasikan nilai karakter bangsa di sekolah.

\section{Hakekat Karakter Bangsa}

Konsep dan definisi karakter diartikan sebagai "the pattern of behavior or personality found in individual or group, moral strengths, self-discipline, reputation" (Webster's New World Dictionary of the American Language). Lickona mendefinisiskan pendidikan karakter yaitu suatu usaha yang disengaja untuk membantu seseorang sehingga ia dapat memahami, memperhatikan dan melakukan nilai-nilai etika yang inti (belajar psikologi.com/pengertian pendidikan karakter). Berdasarkan definisi karakter tersebut dapat dipahami dan dimaknai bahwa hakekat dari karakter merupakan sebuah kebiasaan pribadi atau kelompok dalam kaitanya dengan implementasi nilai-nilai moral dalam kehidupan seseorang setiap hari. Dalam realitas kehidupan pribadi seorang siswa, tidak bisa dipisahkan dari pengaruh lingkungan sekitarnya baik di sekolah maupun di luar sekolah.

Selanjutnya, makna pendidikan karakter adalah pendidikan yang tujuannya membentuk watak pribadi seseorang berdasarkan nilai-nilai moral peradaban bangsa sehingga menjadikan anak didik patuh dan taat terhadap norma-norma agama, sosial, dan budaya. Sebagai warga negara yang berkarakter, dia dapat mengembangkan dirinya dan berperilaku sesuai dengan norma dan ketentuan budaya bangsa. Hal ini, sesuai dengan pesan Undang-Undang Republik Indonesia nomor 20 tahun 2003 tentang Sistem Pendidikan Nasional (UU Sisdiknas). Dalam Pasal 3 UU Sisdiknas menyebutkan, "Pendidikan nasional berfungsi mengembangkan dan membentuk watak serta peradaban bangsa yang bermartabat dalam rangka mencerdaskan kehidupan bangsa, bertujuan untuk berkembangnya potensi peserta didik agar menjadi manusia yang beriman dan bertakwa kepada Tuhan Yang Maha Esa, berakhlak mulia, sehat, berilmu, cakap, kreatif, mandiri, dan menjadi warga negara yang demokratis serta bertanggung jawab". Pesan yang terkandung dalam pasal 3 tesebut adalah warga negara Indonesia harus menjalankan norma-norma dan agama, berahlak mulia, berilmu, dan bersikap demokratis dan bertanggung jawab. Bagaimana menerapkan pesan ini dalam pendidikan? Menjadi pertanyaan penting yang harus dijawab bersama. Tantangan inilah yang perlu dicarikan pemecahannya agar kualitas manusia Indonesia dapat berkembang dengan baik.

Untuk memahami makna pendidikan budaya dan karakter bangsa, maka perlu dikemukakan mengenai pengertian istilah budaya, karakter bangsa, dan pendidikan. Pusat Kurikulum Badan Penelitian dan Pengembangan Kementerian Pendidikan Nasional Jakarta, (2010) memberikan beberapa konsep budaya, dan karakter bangsa seperti yang tertuang dalam pernyataan berikut: Budaya diartikan sebagai keseluruhan sistem berpikir, nilai, moral, norma, dan keyakinan (belief) manusia yang dihasilkan masyarakat. Sistem berpikir, nilai, moral, norma, dan keyakinan itu adalah hasil dari interaksi manusia dengan sesamanya dan lingkungan alamnya. Sistem berpikir, nilai, moral, 
norma, dan keyakinan itu digunakan dalam kehidupan manusia dan menghasilkan sistem sosial, sistem ekonomi, sistem kepercayaan, sistem pengetahuan, teknologi, seni, dan sebagainya. Manusia sebagai makhluk sosial menjadi penghasil sistem berpikir, nilai, moral, norma, dan keyakinan. Akan tetapi dalam interaksi dengan sesama manusia dan alam kehidupan, manusia diatur oleh sistem berpikir, nilai, moral, norma, dan keyakinan yang telah dihasilkannya. Ketika kehidupan manusia terus berkembang, maka yang berkembang sesungguhnya adalah sistem sosial, sistem ekonomi, sistem kepercayaan, ilmu, teknologi, serta seni. Pendidikan merupakan upaya terencana dalam mengembangkan potensi peserta didik, sehingga mereka memiliki sistem berpikir, nilai, moral, dan keyakinan yang diwariskan masyarakatnya dan mengembangkan warisan tersebut ke arah yang sesuai untuk kehidupan masa kini dan masa mendatang.

Karakter adalah watak, tabiat, akhlak, atau kepribadian seseorang yang terbentuk dari hasil internalisasi berbagai kebajikan (virtues) yang diyakini dan digunakan sebagai landasan untuk cara pandang, berpikir, bersikap, dan bertindak. Kebajikan terdiri atas sejumlah nilai, moral, dan norma, seperti jujur, religius, berani bertindak, dapat dipercaya, toleransi, disiplin, kreatif, kerja keras, rasa ingin tahu, peduli lingkungan, tanggung jawab, peduli sosial, cinta damai, semangat kebangsaan, cinta tanah air, hormat kepada orang lain, dan masih banyak sifatsifat baik lainnya. Interaksi seseorang dengan orang lain menumbuhkan karakter masyarakat dan karakter bangsa. Oleh karena itu, pengembangan karakter bangsa hanya dapat dilakukan melalui pengembangan karakter individu seseorang. Akan tetapi, karena manusia hidup dalam ligkungan sosial dan budaya tertentu, maka pengembangan karakter individu seseorang hanya dapat dilakukan dalam lingkungan sosial dan budaya yang berangkutan. Artinya, pengembangan budaya dan karakter bangsa dapat dilakukan dalam suatu proses pendidikan yang tidak melepaskan peserta didik dari lingkungan sosial, budaya masyarakat, dan budaya bangsa. Lingkungan sosial dan budaya bangsa adalah Pancasila. Jadi pendidikan budaya dan karakter bangsa haruslah berdasarkan nilai-nilai Pancasila. Dengan kata lain, mendidik budaya dan karakter bangsa adalah mengembangkan nilai-nilai Pancasila pada diri peserta didik melalui pendidikan hati, otak, dan fisik.

Atas dasar pemikiran itu, pengembangan pendidikan budaya dan karakter sangat strategis bagi keberlangsungan dan keunggulan bangsa di masa mendatang. Pengembangan itu harus dilakukan melalui perencanaan yang baik, pendekatan yang sesuai, dan metode belajar serta pembelajaran yang efektif. Sesuai dengan sifat suatu nilai, pendidikan budaya dan karakter bangsa adalah usaha bersama sekolah. Oleh karena itu, semua guru dan pemimpin sekolah perlu melakukan secara bersama oleh pelaksanaannya melalui semua mata pelajaran dan menjadi bagian yang tak terpisahkan dari budaya sekolah ( Pusat Kurikulum 2010).

\section{Faktor yang Mempengaruhi Karakter Bangsa}

Ada beberapa faktor yang dapat mempengaruhi budaya dan karakter seorang anak atau siswa, antara lain:

\section{1. faktor psikologis.}

Pengaruh kejiwaan seorang anak dapat dilihat dalam beberapa aspek, yaitu pengaruh psikologis dan perkembangan. Dalam membentuk karakter siswa agar mampu mengikuti dan taat pada nilai-nilai moral, agama, dan karakter bangsa, maka tidak bisa lepas dari aspek psikologis dan perkembangan anak atau siswa tersebut. Jika tidak mengetahui perkembangan anak dan cara mempelakukan mereka maka dapat dipastikan akan menemui kendala, tantangan, dan bahaya besar akibat pengaruh psikologis. Pengaruh ini terjadi akibat dari masa puber mereka yang belum matang terutama mengenai konsep diri yang kurang baik. Hanya sedikit anak yang melampaui masa puber tanpa mengembangkan konsep diri yang kurang menyenangkan. Salah atur dan salah memberikan perlakuan dan tindakan pada anak pada masa pubertas akan menyebabkan perkembangan konsep diri kurang baik selama masa puber melampuai batas baik batas norma-norma, budaya dan karakter itu sendiri. Berkaitan dengan pubertas ini, Hurlock (1980:197) mengatakan bahwa hampir semua anak puber mempunyai konsep diri yang tidak realistis mengenai penampilan dan kemampuanya kelak. Perilaku yang tidak realistis dapat diakibatkan oleh masa pubertas yang cenderung ingin mencoba sesuatu hal baru. Coba-coba dan menampakkan diri sebagai seorang yang kuat dan diakui keberadaanya merupakan sebuah karakter individu seorang remaja. Jika hal ini tidak dimbangi dengan contoh dan perlakuan positif dari lingkungan, maka anak tersebut akan cenderung melakukan hal-hal yang negatif. Peran lingkungan keluarga, sekolah dan masyarakat dalam memberi contoh kepada anak sangat besar dan hal ini akan membentuk watak dan karakter si anak tersebut menjadi karakter yang baik sesuai dengan normanorma agama, hukum, budaya, dan norma-norma positif lainnya. Sejalan dengan pendapat Hurlock 
(1980:197), Albert Bandura (1973, 1986 dalam dalam Nevid, Rathus, dan Greene, terjemahan Murad dkk (2005:207) menegaskan ada perilaku sosial-kognitif yang mengatakan bahwa agresi merupakan perilaku yang dipelajari, dimunculkan melalui cara yang sama seperti perilaku-perilaku yang lain.

\section{Faktor Budaya dan Transformasi Nilai Karakter Bangsa melalui Jalan Hidup}

Transformasi nilai karakter bangsa merupakan sebuah cara mempertahankan karakter bangsa terhadap nilai-nilai luhur bangsa tersebut. Bukan hanya contoh dan tindakan-tindakan yang harus dilakukan oleh generasi sesudahnya, tapi makna dan nilai-nilai historis yang mencerminkan kebesaran sebuah bangsa atau makna hidup serta karakter bangsa yang melaksanakannya. Keajegan dan kekonsistenan sebuah bangsa dan anak bangsa dalam melangsungkan nilai-nilai budaya dan karakter bangsanya menjadikan bangsa tersebut besar dan dihormati oleh bangsa lain. Namun, jika bangsa tersebut tidak menghargai karakter bangsanya sendiri akan menjadi bangsa yang hina dan tidak dihormati oleh orang lain atau bangsa lain.

Untuk memberikan gambaran mengenai sebuah bangsa yang konsisten melaksanakan nilai-nilai karakter dan budaya bangasnya adalah bangsa Jepang. Dalam kehidupan berbangsa dan bernegara, bangsa Jepang dikenal patuh dan taat terhadap nilai-nilai luhur bangsanya yang mereka anut sepanjang kehidupan sehari-hari sebagai warga negara. Tata nilai dan karakter itu dikenal dengan Bushido yaitu sebagai tata cara ksatria, sebuah kode etik kepahlawan golongan samurai dalam feodalisme Jepang. Sedangkan samurai sendiri adalah sebuah strata sosial penting dalam tatanan masyarakat feodalisme Jepang. Makna bushido adalah sikap rela mati demi negara dan kaisar hingga para samurai rela mempertaruhkan nyawanya demi itu. Jika ia gagal, ia akan melakukan harakiri (bunuh diri dengan menusukkan pisau, membelah perutnya) (http://mandazzahra. wordpress. com/2008/06/10/ restorasimeiji).

Pada buku Taro Sakamato terjemahan Sylvia Tiwon (1982) (http://mandaazzahra. wordpress. com/2008/06/10/restorasimeiji), pada halaman pengantar, Mochtar Lubis memaparkan bahwa kekuatan utama Jepang adalah kesatuan bangsa, kesatuaan kebudayaan, dan nilai-nilainya. Sebaliknya, bangsa kita kurang menghargai nilai-nilai dan karakter bangsanya sendiri sebagai bangsa yang sopan, beradab, gotong royong, sesuai dengan nilai-nilai yang terkandung dalam pembukaan UUD 45 dan
Pancasila serta nilai religious. Sekarang ini, anak bangsa ini sudah jauh melenceng dari pelaksanaan karakter bangsa yang pernah dicontohkan oleh para pendiri bangsa. Bung Hatta, memberikan contoh karakter pemimpin yang bersih. Tapi sekarang kita seakan bangga ketika negeri ini juga meraih medali emas dalam Coruptor Olympiad. Belum lagi peserta kompetisi itu adalah orang-orang yang disegani dan dihormati rakyat. Reformasi yang telah bergulir selalu meneriakkan pemberantasan korupsi, hanya melahirkan benih-benih yang makin berjamur. Masalah lain yang sebenarnya perlu diajarkan untuk anak-anak $\mathrm{SD}$, masih dipraktekkan oleh para pegawai hingga pejabat yang duduk di dewan sana.

Pembinaan karakter di tengah besarnya modalitas Indonesia untuk menjadi lebih optimal dalam tatanan pembangunan peradaban harus menjadi prioritas utama. Apalagi di tengah bangsa yang juga mengarungi luasnya samudera global. Karena yang perlu dicermati, hanya bangsa-bangsa yang memiliki karakter kuat dan tangguh akan sanggup menghadapi berbagai tantangan pembangunan global. Bangsa yang kuat dan tangguh akan sanggup untuk mengubah berbagai tantangan itu menjadi peluang menguntungkan. Kita tak perlu jauh meneropong ke arah Barat sana. Apa yang dicapai bangsa Jepang dewasa ini adalah perjalanan yang memeras keringat. Tanpa sumber alam yang berarti, jumlah penduduk yang banyak dan padat untuk sebuah negeri kecil, ia tidak saja dapat tetap menghidupi rakyatnya, tetapi bahkan membuat bangsa Barat "gigit jari". Yang "besar" harus punya malu belajar kepada yang "kecil". Indonesia kaya dengan sumber daya alam dan sumber daya manusia serta kawasan luas, tidak perlu malu belajar sekaligus berefleksi pada transformasi kebangkitan bangsa Jepang. Karena karakter yang dimiliki suatu bangsa ditentukan oleh karakter warga bangsanya. Mereka yang maju dan berhasil menjadi negara-negara terkemuka umumnya memiliki warga yang sarat dengan karakter unggul dan belajar dari keberhasilan negeri lain. Pada masamasa gejala politik, sosial, dan ekonomi. Bangsa Jepang pun tidak segan-segan menyerap pola pikir dan cara hidup bangsa lain sebagai titik tolak untuk perubahan bangsanya. Jika ingin kemakmuran 1 tahun, tumbuhkan benih Jika ingin kemakmuran 10 tahun, tumbuhkanlah pohon, Jika ingin kemakmuran 100 tahun, tumbuhkanlah manusia. Kata-kata di atas merupakan analek konfusius yang dipakai para pemimpin Jepang untuk memajukan negaranya. Makna tumbuhkanlah manusia berarti harus bermula pada karakter bangsa. Jika Jepang bisa, Indonesiaku 
pun harus bisa. (http://mandaazzahra.wordpress. com/2008/06/10/restorasimeiji).

\section{Landasan Pedagogis Pendidikan Karakter Bangsa}

Pendidikan budaya dan karakter bangsa pada dasarnya adalah pengembangan nilai-nilai yang berasal dari pandangan hidup atau ideologi bangsa Indonesia, agama, budaya, dan nilai-nilai yang terumuskan dalam tujuan pendidikan nasional. Undang-Undang Republik Indonesia nomor 20 tahun 2003 tentang Sistem Pendidikan Nasional (UU Sisdiknas) Pasal 1 ayat 1 mengatakan bahwa pendidikan adalah usaha sadar dan terencana untuk mewujudkan suasana belajar dan proses pembelajaran agar peserta didik secara aktif mengembangkan potensi dirinya untuk memiliki kekuatan spiritual keagamaan, pengendalian diri, kepribadian, kecerdasan, akhlak mulia, serta keterampilan yang diperlukan dirinya, masyarakat, bangsa, dan negara. Dengan pendidikan yang dilakukan secara sadar dan terencana, pesan pedagogis yang akan diajarkan pada peserta didik akan mampu membawa dan mengarahkan mereka untuk melakukan dan mengamalkan nilai-nilai yang terkandung dalam pembukaanUUD 1945 dan nilai yang ada dalam Pancasila. Usaha yang dilakukan dalam kegiatan pendidikan berpedoman pada nilainilai budaya bangsa seperti yang tertuang dalam pembukaan UUD 1945 dan pancasila dan dilakukan dengan sadar.

Pendidikan yang dilakukan dengan perencanaan yang tepat dan terintegrasi dengan nilai-nilai budaya dalam lingkungan serta sesuai dengan kaidahkaidah yang berlaku, maka tentu akan menghasilkan sifat dan karakter yang baik. Pendidikan yang tidak dilandasi oleh prinsip itu akan menyebabkan peserta didik jauh dari budayanya. Ketika hal ini terjadi, maka mereka tidak akan mengenal budayanya dengan baik sehingga ia menjadi orang "asing" dalam lingkungan budayanya. Selain menjadi orang asing, yang lebih mengkhawatirkan adalah dia menjadi orang yang tidak menyukai budayanya.

Pengembangan nilai-nilai dasar karakter itu memerlukan sebuah proses yang berkelanjutan dan dilakukan secara terintegrasi dalam setiap bidang studi. Dalam mengembangkan pendidikan karakter bangsa, maka perluk menyadarkan siswa melalui refleksi dalam kegiatan pendidikan agar tumbuh kesadaran dan mengenal dirinya dan bangsanya. Kesadaran tersebut hanya dapat dibangun melalui pemberian pengalaman dan penjelasan mengenai sejarah bangsa di masa lalu agar siswa tersebut mengenal budaya bangsanya. Selain itu, pendidikan harus membangun kesadaran, pengetahuan, wawasan, dan nilai berkenaan dengan lingkungan tempat diri dan bangsanya hidup (geografi), nilai yang hidup di masyarakat (antropologi), sistem sosial yang berlaku dan sedang berkembang (sosiologi), sistem ketatanegaraan, pemerintahan, dan politik (ketatanegaraan/politik/kewarganegaraan), bahasa Indonesia dengan cara berpikirnya, kehidupan perekonomian, ilmu, teknologi, dan seni. Untuk mecapai tujuan ini, maka perlu ada upaya pengembangan nilainilai yang menjadi dasar bagi pendidikan budaya dan karakter bangsa.

\section{Fungsi Pendidikan Karakter Bangsa}

Fungsi pendidikan budaya dan karakter bangsa adalah: 1) pengembangan: pengembangan potensi peserta didik untuk menjadi pribadi berperilaku baik; ini bagi peserta didik yang telah memiliki sikap dan perilaku yang mencerminkan budaya dan karakter bangsa, 2) perbaikan: memperkuat kiprah pendidikan nasional untuk bertanggung jawab dalam pengembangan potensi peserta didik yang lebih bermartabat, dan 3) penyaring: untuk menyaring budaya bangsa sendiri dan budaya bangsa lain yang tidak sesuai dengan nilai-nilai budaya dan karakter bangsa yang bermartabat.

\section{Nilai-nilai dalam Pendidikan Karakter Bangsa}

Nilai-nilai yang dikembangkan dalam pendidikan budaya dan karakter bangsa mencakup nilai agama, panca sila, dan budaya. Nilai-nilai tersebut secara rinci berdampak pada perlunya nilai religious, jujur, toleransi, disiplin, kerja keras, kreatif, mandiri, demoratis, rasa ingin tahu, semangat kebangsaan, cinta tanah air, menghargai prestasi, bersahabat/ komuniktif, cinta damai, gemar membaca, peduli lingkungan, peduli sosial, dan tanggung-jawab (Pusat Kurikulum, Balitbang Kendiknas. 2010).

Kajian ini menggunakan metode analisis dokumen. Teknik yang digunakan adalah mengkaji dokumen dan membandingkannya dengan realitas empirik yang terjadi dalam masyarakat serta kondisi yang terjadi di sekolah terhadap perilaku siswa berdasarkan kasus-kasus tertentu yang mempengaruhi karakter siswa dalam penyelenggraan pendidikan di sekolah. Langkah-langkah yang dilakukan adalah mengkaji dokumen yang berkaitan dengan modus dan fenomena perubahan karakter di masyarakat. Realitas karakter yang ditunjukkan oleh perilaku masyarakat dikaitkan dengan kondisi empirik yang terjadi di sekolah mengenai perubahan karakter siswa. Dampak dari perubahan perilaku yang berpengaruh terhadap perubahan karakter siswa dan implikasinya terhadap pendidikan dikombinasikan dan ditarik simpulanya sebagai dasar dalam memberikan alternatif kebijakan dalam mengimplementasikan pendidikan karakter di 
sekolah.

\section{PEMBAHASAN}

Berbagai persoalan karakter dalam dunia pendidikan yang menjadi isu utama dan solusi alternatif yang dapat dilakukan oleh kementerian pendidikan dan jajarannya adalah:

1. Faktor yang mempengaruhi melemahnya pendidikan karakter di kalangan pendidikan

Korupsi, kekerasan, kejahatan seksual, perusakan, perkelahian, kehidupan ekonomi yang konsumtif, dan kehidupn politik yang tidak kondusif. Melemahnya implementasi karakter bangsa dapat dilihat pada forum resmi, misalnya; di lembaga terhormat Dewan Perwakilan Rakyat (DPR) kita sering kita tonton dan saksikan dalam televisi, para wakil rakyat yang dianggap terhormat menunjukkan sifat yang melanggar norma kehidupan dan karakter bangsa kita dengan memperlihatkan sifat arogansi individu dan kelompok. Perilaku masyarakat yang banyak menyimpang dari nilai-nilai agama, moral, kebangsaan dan budaya tidak bisa dihindari oleh peserta didik yang coba-coba mengikuti perilaku tersebut.

Pergaulan bebas yang dilakukan siswa Sekolah Menengah Pertama (SMP), Sekolah Menengah Atas (SMA), dan Sekolah Menengah Kejuruan (SMK) di masyarakat, beberapa video adegan porno yang tertangkap polisi yang sempat disiarkan dalam televisi, narkoba. Semua faktor di atas merupakan faktor yang dapat melemahkan karakter teurtama di kalangan siswa. Oleh karena itu, untuk memperkuat karakter di bidang pendidikan khususnya di kalangan pelajar tingkat sekolah Dasar (SD) sampai tingkat sekolah Menengah faktor-faktor tersebut perlu di hindari dengan memperkuat pendidikan agama, pancasila dan kebersamaan pada tingkat pendidikan dasar dan menengah.

2. Tindakan yang perlu dilakukan oleh kementerian pendidikan dalam mengatasi melemahnya nilai moral bangsa di lingkungan pendidikan sekolah

Tindakan yang pertama untuk memperkuat moral anak adalah membangun dan memperkuat pendidikan karakter melalui pendidikan agama dalam keluarga. Pendidikan karakter tidak hanya dibangun melalui as $\urcorner$ pek ilmu pengetahuan semata-semata tetapi juga harus ter-integrasi secara holistik dengan as $\urcorner$ pek sikap dan pe $\neg$ ri $\neg$ lakunya. Membangun aspek-aspek tersebut perlu sentuhan ka $\urcorner$ sih sayang dan perhatian keluarga. Dalam keluargalah dasar pendidikan yang pertama dan utama ditanamkan. Melalui keluarga pendidikan dapat dilakukan dengan 154 Jurnal IImiah VISI P2TK PAUDNI - Vol. 9, No.2, Desember 2014 berbagai cara dan metode sesuai dengan prinsipprinsip yang dianut oleh masing-masing keluarga.

Bagi keluarga muslim misalnya, ayah dan ibu sebagai orang tua akan berusaha memberikan pendidikan yang baik pada anak-anaknya melalui penananman agama islam misalnya melaksanakan sholat, puasa, mengeluarkan zakat, dan sebagainya. Tidak ada seorangpun keluarga yang menginginkan anak-anaknya menjadi seorang yang tidak baik walaupun mereka kadangkala dianggap sebagai bapak dan ibu yang tidak baik atau katakanlah orang tua yang jahat sekalipun.

Ada beberapa cara yang dilakukan oleh keluarga dalam membangun karakter anak antara lain membangun kejujuran, penanaman nilai-nilai agama, keikhlasan beribadah, beraktivitas, peduli sesama, dan kebersamaan. Selain memperkuat pendidikan dalam keluarga, Kementerian Pendidikan dan Kebudayaan dapat melakukan kerjasama dengan media seperti televisi (TV) untuk mengurangi siaransiaran yang dapat memperlemah moral, kejujuran atau toleransi sesama. Misalnya. mengurangi tontonan TV setiap hari karena TV merupakan salah satu cermin budaya bangsa saat ini. Umumnya budaya yang ditampilkan terbatas pada seni suara dan seni akting, yang memang disukai pemirsa tua dan muda. Acara TV umumnya mengikuti selera, bukan visi-misi yang sesuai dengan visi-misi masa depan bangsa. Selain itu, Kemdikbud juga dapat meggiatkan kembali tampilan budaya-budaya asli Indonesia yang dulu sering ditampilkan di TV seperti: acara wayang, kesenian daerah, kerajinan khas daerah, budaya khas gotong royong Indonesia yang kesemuanya ini merupakan cermin budaya dan karakter bangsa Indonesia. Nampaknya, para remaja sudah mulai asing dengan budaya khas Indonesia, apalagi nilai-nilai yang terkandung di dalamnya.

Pendidikan budaya dan karakter bangsa harus dikembangkan secara komprehensif sebagai proses pembudayaan. Oleh karena itu, pendidikan dan kebudayaan secara kelembagaan perlu diwadahi secara utuh. Pendidikan budaya dan karakter bangsa merupakan tanggung jawab bersama antara pemerintah, masyarakat, sekolah, dan orangtua. Oleh karena itu, pelaksanaan budaya dan karakter bangsa harus melibatkan keempat unsur tersebut. Dalam upaya merevitalisasi pendidikan dan budaya karakter bangsa diperlukan gerakan nasional guna menggugah 
semangat kebersamaan dalam pelaksanaanya di lapangan

3. Cara praktis dalam mengimplementasikan nilai karakter bangsa di sekolah

Memperkuat penerapan agama di sekolah dan di masyarakat adalah salah satu cara yang ampuh dalam membangun karakter siswa. Oleh karena itu, kehidupan individu, masyarakat, dan bangsa selalu didasari pada ajaran agama dan kepercayaannya. Secara politis, kehidupan kenegaraanpun didasari pada nilai-nilai yang berasal dari nilai agama. Atas dasar pertimbangan itu, maka nilai-nilai pendidikan budaya dan karakter bangsa harus didasarkan pada nilai-nilai dan kaidah yang berasal dari agama. Pancasila sebagai landasan hidup berbangsa dan bernegara bangsa Indonesia ditegakkan atas prinsipprinsip kehidupan kebangsaan dan kenegaraan. Pancasila terdapat pada Pembukaan UUD 1945 dan dijabarkan lebih lanjut dalam pasal-pasal yang terdapat dalam UUD 1945. Artinya, nilai-nilai yang terkandung dalam Pancasila menjadi nilai-nilai yang mengatur kehidupan politik, hukum, ekonomi, kemasyarakatan, budaya, dan seni. Pendidikan budaya dan karakter bangsa bertujuan mempersiapkan peserta didik menjadi warga negara yang lebih baik, yaitu warga negara yang memiliki kemampuan, kemauan, dan menerapkan nilai-nilai Pancasila dalam kehidupannya sebagai warga negara.

Memperkuat pelaksanaan pendidikan karakter dalam kurikulum dan pembelajaran adalah cara praktis dalam melaksanakan pendidikan karakter di sekolah. Pada prinsipnya, pengembangan budaya dan karakter bangsa tidak dimasukkan sebagai pokok bahasan tetapi terintegrasi ke dalam mata pelajaran, pengembangan diri, dan budaya sekolah. Oleh karena itu, guru dan sekolah perlu mengintegrasikan nilainilai yang dikembangkan dalam pendidikan budaya dan karakter bangsa ke dalam Kurikulum, Silabus, dan Rencana Program Pembelajaran (RPP) yang sudah ada.

Melaksanakan kegiatan-kegiatan penanaman nilai-nilai budaya dan karakter di sekolah melalui penerapan nilai-nilai di sekolah mulai dari awal peserta didik masuk sampai selesai pada setiap satuan pendidikan. Proses tersebut sebaiknya dimulai dari kelas 1 Sekolah Dasar (SD) atau tahun pertama dan berlangsung paling tidak sampai Sekolah Menengah Atas (SMA). Melaksanakan penanaman nilai karakter bangsa pada semua mata pelajaran, pengembangan diri, dan budaya sekolah, mensyaratkan bahwa proses pengembangan nilai-nilai budaya dan karakter bangsa dilakukan melalui setiap mata pelajaran, dan dalam setiap kegiatan intra kurikuler dan ekstra kurikuler.

Mengintegrasikan nilai karakter bangsa pada semua mata pelajaran; dalam mata pelajaran agama, bahasa Indonesia, PKn, IPA, IPS, matematika, pendidikan jasmani dan kesehatan, seni, dan ketrampilan. Materi pelajaran biasa digunakan sebagai bahan atau media untuk mengembangkan nilai-nilai budaya dan karakter bangsa. Oleh karena itu, guru tidak perlu mengubah pokok bahasan yang sudah ada, tetapi menggunakan materi pokok bahasan itu untuk mengembangkan nilainilai budaya dan karakter bangsa. Juga, guru tidak harus mengembangkan proses belajar khusus untuk mengembangkan nilai. Suatu hal yang selalu harus diingat bahwa satu aktivitas belajar dapat digunakan untuk mengembangkan kemampuan dalam ranah kognitif, afektif, dan psikomotor.

Selain kegiatan-kegiatan nyata tersebut, sekolah juga dapat melaksanakan kegiatan rutin sekolah, kegiatan spontan, keteladanan, pengkondisian, pengintegrasian dalam mata pelajaran, budaya sekolah, pengembangan proses pembelajaran, dan penilaian hasil belajar. Meningkatkan prestasi siswa dalam olimpiade sains tingkat dunia, kreativitas pentas seni, prestasi dalam bidang olahraga, pembuatan laptop, pembuatan kendaraan khususnya para siswa SMK, dan kreativitas positif lainnya.

Penilaian pencapaian pendidikan nilai budaya dan karakter didasarkan pada indikator-indikator tertentu. Contoh, indikator untuk nilai jujur pada satu semester dirumuskan dengan "mengatakan dengan sesungguhnya perasaan dirinya mengenai apa yang dilihat, diamati, dipelajari, atau dirasakan" maka guru mengamati (melalui berbagai cara) apakah yang dikatakan peserta didik itu jujur mewakili perasaan dirinya.

Langkah lain adalah mengntegrasikan nilainilai budaya dan karakter bangsa ke dalam dokumen kurikulum. Kurikulum sebagai pedoman guru dalam melaksanakan pembelajaran dapat memuat pendidikan karakter yang terintegrasi untuk semua bidang studi dan tidak perlu menjadikan pendidikan karakter terpisah dan sebagai satu bidang studi tersendiri. Pendidikan karakter di sekolah berada pada pundak seorang guru. Konsistensi dalam pendidikan karakter tidak sekedar memberitahu pa yang harus dilakukan oleh siswa tapi lebih dari itu member contoh dengan perbuatan dan tindakan atau melakukan sesuatu yang nyta dan dapat dicontoh oleh siswa karena prilaku guru dalam keseharian tentu menjadi model. Guru dalam arti luas tentu termasuk orangtua, tokoh masyarakat, maupun aparatur pemerintah. Perilaku- 
perilaku mereka akan ikut membentuk karakter peserta didik. Tindak-tanduknya sedikit-banyak akan ditiru oleh anak. "Guru itu digugu dan ditiru” bukan "Guru kencing berdiri, murid kencing berlari”. (IGK Tribana:http://www. balipost.co.id/mediadetail.php?module).

\section{PENUTUP}

\section{Kesimpulan}

Faktor-faktor yang mempengaruhi melemahnya pendidikan karakter di kalangan pendidikan adalah korupsi, kekerasan, kejahatan seksual, perusakan, perkelahian, kehidupan ekonomi yang konsumtif, dan kehidupn politik yang tidak kondusif. Untuk itu diperlukan penguatan pendidikan budaya dan karakter bangsa. Mengembangkan dan memperkuat potensi pribadi juga dapat menyaring pengaruh dari luar yang akhirnya dapat membentuk karakter peserta didik yang dapat mencerminkan budaya bangsa Indonesia. Upaya pembentukan karakter sesuai dengan budaya bangsa ini tentu tidak semata-mata hanya dilakukan di sekolah melalui serangkaian kegiatan belajar mengajar baik melalui mata pelajaran maupun serangkaian kegiatan pengembangan diri yang dilakukan di kelas dan luar sekolah. Pembiasaanpembiasan dalam kehidupan, seperti: religius, jujur, disiplin, toleran, kerja keras, cinta damai, tanggungjawab, dsb. perlu dimulai dari lingkup terkecil seperti keluarga sampai dengan cakupan yang lebih luas di masyarakat. Nilai-nilai tersebut tentunya perlu ditumbuhkembangkan sehingga dapat membentuk pribadi karakter peserta didik yang sesuai dengan budaya bangsa Indonesia. Pembentukan budaya sekolah dapat dilakukan oleh sekolah melalui kegiatan perencanaan, pelaksanaan pembelajaran, dan penilaian yang bersifat komprehensif. Perencanaan di tingkat sekolah pada intinya adalah melakukan penguatan dalam penyusunan kurikulum, seperti menetapkan visi, misi, tujuan, struktur kurikulum, kalender akademik, dan penyusunan silabus. Keseluruhan perencanaan sekolah yang bertitik tolak dari analisis kekuatan dan kebutuhan sekolah yang dapat menghasilkan program pendidikan yang lebih terarah pada sikap prilaku yang dapat membentuk ahklak budi luhur.

Tindakan yang perlu dilakukan oleh kementerian pendidikan dalam mengatasi melemahnya nilai moral bangsa di lingkungan pendidikan sekolah adalah membangun dan mempekuat pendidikan karakter dalam keluarga, membangun kejujuran, penanaman nilai-nilai agama, keikhlasan beribadah dan beraktivitas, peduli sesama, dan kebersamaan.

Langkah solusi praktis yang dapat dilakukan oleh sekolah dalam memgatasi dan mengaurangi dampak reduksinya moral terhadap implementasi nilai karakter bangsa di sekolah, antara lain: memperkuat penerapan agama di sekolah dan di masyarakat, memperkuat pelaksanaan pendidikan karakter dalam kurikulum dan pembelajaran, melaksanakan kegiatan-kegiatan (penanaman nilai-nilai budaya dan karakter di sekolah, mengintegrasikan nilai karakter bangsa pada semua mata pelajaran; dalam mata pelajaran agama, bahasa Indonesia, PKn, IPA, IPS, matematika, pendidikan jasmani dan kesehatan, seni, dan ketrampilan, guru menerapkan prinsip "tut wuri handayani" dalam setiap perilaku yang ditunjukkan peserta didik, keteladanan, pembelajaran pendidikan budaya dan karakter bangsa menggunakan pendekatan proses belajar peserta didik secara aktif dan berpusat pada anak; dilakukan melalui berbagai kegiatan di kelas, sekolah, dan masyarakat). Saran

Untuk mengatasi faktor-faktor yang mempengaruhi melemahnya pendidikan karakter di kalangan pendidikan, masyarakat khususnya keluarga hendaknya menanamkan nilai-nilai agama yang lebih intensif pada anggota keluarga dengan cara memberikan pemahaman nilai-nilai agama, moral, dan kejujuran pada semua anggota keluarag. Orangtua memberikan contoh dengan melakukan sesuatu sesaui dengan norma-nrma agama, budaya dengan mengesampingkan informasi dan berita baik dari media TV, radio, dan media cetak yang tidak sesaui dengan norma agama.

Kementerian pendidikan dan kebudayaan dapat menerapkan disiplin yang leih ketat pada pada sekolah terutama sekolah-sekolah yang siswanya melakukan perbuatan anarkis. Melalui dinas pendidikan, kemdikbud dapat menetapkan aturan yang lebih ketat terhadap sekolah untuk mengawasi siswa dan guru sehingga dapat melaksanakan nilainilai karakter bangsa melalui inetgrasi pendidikan karakter dalam kurikulum danpenerappnya dalam semua bidang studi.

Langkah solusi praktis yang dapat dilakukan oleh sekolah dalam memgatasi dan mengaurangi dampak reduksinya moral terhadap implementasi nilai karakter bangsa di sekolah. Sekolah disarankan untuk membuat program seni yang menarik sekaligus memperthankan budaya bangsa seperti tari Aceh, Bali, dan tari-tarian daerah lain. Demikian juga program olah 
raga seperti olah raga futsal, atletik, sepak bola, catur, basketball, bulu tangkis, dan lainnya. Disamping itu, sekolah perlu membuat program-program yang inovatif yang diminati oleh peserta didik agar mereka mau mengikutinya. Siswa agar memilih kegiatan-kegiatan yang dapat meningkatkan nilai akademik dan prestasi non akademik seperti tambahan pelajaran, olah raga, dan kesenian dan menghindari kegiatan-kegiatan yang mengarah pada kenakalan remaja. Guru dalam menyusun program perlu memperhatikan minat dan motivasi peserta didik dalam memilih kegiatan yang diikutinya agar lebih bermanfaat bagi dirinya.

\section{DAFTAR PUSTAKA}

Badan Narkotika Nasional Republik Indonesia (2004). Penggunaan narkotika dan obat Terlarang.

Bushido. (2008). Sebuah transformasi nilai karakter bangsa melalui jalan hidup Samurai (Refleksi untuk Indonesiaku. (http://mandaazzahra. wordpress. com//06/10/ restorasimeiji-sebuahpembelajaran-bagi-indonesia/diakses 27 September 2008

Departemen Kesehatan Republik Indonesia (2008). Anak-anak usia 5 tahun sudah mulai merokok

Guralnik, D.B. (ed). Webster's new world dictionary of the american language. Meriam and Webster Inc. Sampaloc Manila.

http://mandaazzahra.wordpress.com/2008/06/10/ restorasimeiji

Hurlock, E.B. (1980). Psikologi perkembangan. Suatu pendekatan sepanjang rentang kehidupan. Jakarta: Erlangga.
Kementerian Pendidikan Nasional. (2010). Pedoman pendidikan karakter bangsa. Jakarta: Pusat Kurikulum Badan Penelitian dan Pengembangan Kemdikbud.

Thomas, L. Pengertian pendidikan karakter. Diakses pada tanggal 27 September 2008 dari http:// belajar psikologi.com/pengertian pendidikan karakter

Nevid, Jeffrey S. R., Spencer A. G., Beverly/ psikologi abnormal. (2005). Edisi 5. Jilid 2. Terjemahan Jenette Murad, dkk. Jakarta: Erlangga.

TVOne, 20 Maret 2020. Anak-anak usia 5 tahun sudah mulai merokok. Komnas Perlindungan Anak bekerja sama dengan Lembaga Perlindungan Anak (LPA).

Undang-Undang Republik Indonesia Nomor 20 Tahun 2003 tentang Sistem Pendidikan Nasional 